\title{
Association of the heart fatty acid-binding protein gene with quality of carcass and meat traits in pigs
}

\author{
[Associação entre o gene da proteína de ligação de ácidos graxos - coração com características de carcaça e \\ qualidade da carne em suínos]
}

\author{
F.C. Figueiredo, P.S. Lopes, A.P.G. Pinto, D.A.F. Paiva, P.T. Mendonça, S.E.F. Guimarães* \\ Departamento de Zootecnia - UFV \\ Av. P.H. Rolfs, s/n \\ 36570-000 - Viçosa, MG.
}

\begin{abstract}
The heart fatty acid-binding protein $(H F A B P)$ gene was sequenced in parental animals of a $\mathrm{F} 2$ crossing of boars of the Brazilian native Piau breed with commercial sows (Landrace $\mathrm{x}$ Large White $\mathrm{x}$ Pietrain). Primers used for PCR were designed to amplify four exons of the gene. The PCR products were sequenced and compared with the GenBank sequences. Differences between the generated sequences and the GenBank sequences were observed for both genetic groups. A total of 246 F2 animals were genotyped using the Hinf I restriction enzyme. Two genotypes were identified, 198 being animals $\mathrm{HH}$ and $48 \mathrm{Hh}$. The Hinf I SNP was significantly associated with weights of loin (bone-in) $(\mathrm{P}<0.05)$, jowl $(\mathrm{P}<0.05)$, sirloin $(\mathrm{P}<0.10)$, and kidneys $(\mathrm{P}<0.01)$. These results showed the potential of the H-FABP gene in marker-assisted selection programs for carcass traits in pigs.
\end{abstract}

Keywords: swine, candidate gene, molecular marker, DNA polymorphism, DNA sequencing

\section{RESUMO}

O gene da proteína de ligação de ácidos graxos - coração foi seqüenciado em animais parentais de um cruzamento F2 entre varrões da raça nativa brasileira Piau e fêmeas comerciais (Landrace x Large White $x$ Pietrain). Os primers utilizados na reação em cadeia da polimerase foram desenhados para amplificarem os quatro éxons do gene. Os fragmentos amplificados foram seqüenciados e comparados com a seqüencia do gene depositada no GenBank. Foram observadas divergências entre as seqüencias geradas e as do GenBank para ambos os grupos genéticos. Foram genotipados 246 animais F2 utilizando-se a enzima Hinf I. Dois genótipos foram identificados, sendo 198 animais HH e 48 animais Hh. O polimorfismo apresentou efeito sobre o peso total do carré $(P<0,05)$, o peso da papada $(P<0,05)$, o peso do filezinho $(P<0,10)$ e o peso dos rins $(P<0,01)$. Os resultados indicam que o gene da $H-F A B P$ apresenta potencial para aplicação em programas de seleção assistida por marcadores moleculares em suinos.

Palavras-chave: suino, gene candidato, marcador molecular, polimorfismo, seqüenciamento de DNA

\section{INTRODUCTION}

The consumer market of pork demands quality, especially in Europe and North America. Animal breeding programs have focused on the production of animals with lower backfat thickness and higher carcass lean meat content, but undesirable genetic gains have been reached in the meat quality traits, especially for the intramuscular fat content (Merks, 2000).

Molecular genetics is a tool that may improve the efficiency of selection programs since it permits the detection of genes or loci related to

Recebido em 15 de janeiro de 2007

Aceito em 29 de janeiro de 2008

Autor para correspondência (corresponding author)

E-mail: sfacioni@ufv.br 
reproduction, performance, carcass, and meat quality traits. The data obtained by molecular studies, along with traditional selection methods, may increase the accuracy of selection and increase the response to selection. In general, marker-assisted selection is more advantageous for the low heritability traits, or those limited by sex, or in the case of phenotypes that are difficult to measure in the living animal (Dekkers, 2004).

The heart fatty acid-binding protein ( $H F A B P$ ) gene has significant effects on economically important traits for the pig industry (Gerbers et al., 1999). Allelic variants of this gene have been associated to different patterns of intramuscular fat deposition (Qian et al., 1999), as well as to other meat quality, carcass cut, carcass yield, and performance traits. The objective of the present study was to identify allelic variants of the $H F A B P$ gene and to determine the effect of these variations on carcass and pork traits in F2 animals, aiming their application in pig breeding programs.

\section{MATERIAL AND METHODS}

The experiment designed to obtain data regarding phenotypic traits was carried out at the Pig Breeding Farm, Departamento de Zootecnica, Universidade Federal de Viçosa (UFV), Viçosa, Minas Gerais, Brazil. More details can be obtained in Soares et al. (2006).
Briefly, genotype and phenotype data were obtained from an F2 design. For this, two boars of the native Brazilian breed Piau were mated with 18 commercial sows (Landrace $\mathrm{x}$ Large White $\times$ Pietrain).

For the detection of allelic variants, DNA samples from 14 parental animals (12 commercial sows and both native Brazilian Piau boars) were analyzed. The DNA samples were processed at the Laboratory of Animal Biotechnology, UFV. DNA from parental, F1, and F2 animals was blood extracted by phenolchloroform purification after proteinase $\mathrm{K}$ treatment, as described by Sambrook et al., (1989), and stored in Tris-EDTA at $-20^{\circ} \mathrm{C}$.

The primers for the $H F A B P$ gene sequence, described in Table 1, were designed based on the GenBank reference sequences, under the accession numbers X98558 (promoter and exon I), Y16180 (exons II and III), and Y16181 (exon IV). The amplification reactions consisted of $1 \mathrm{U}$ Taq polymerase, $0.2 \mathrm{mM}$ dNTPs, $0.2 \mu \mathrm{M}$ of each forward and reverse primers, $20 \mathrm{mM}$ Tris- $\mathrm{HCl} \mathrm{pH}$ 8.3 , and $50 \mathrm{mM} \mathrm{KCl}$. The $\mathrm{Mg}$ concentrations ranged from 2 to $3 \mathrm{mM}$ according to the primer amplification pattern and 25ng genomic DNA was used per reaction in a final volume of $10 \mu \mathrm{l}$. The amplification pattern of the markers was firstly observed in $8 \%$ polyacrylamide gels stained with silver nitrate.

Table 1. Primer sets used to amplify $H F A B P$ promoter and exonic regions

\begin{tabular}{|c|c|c|c|}
\hline Region & Primer sequence & $\begin{array}{c}\text { Temp* } \\
\left({ }^{\circ} \mathrm{C}\right)\end{array}$ & Fragment size (bp) \\
\hline \multirow{2}{*}{$\begin{array}{l}\text { Promoter } \\
\text { exon I }\end{array}$} & 5'GGAGGGACCAGGAAACCGAAG 3' & 60 & \multirow{2}{*}{478} \\
\hline & 5'CAGCCCAACATCCCGAGTCGT 3' & 60 & \\
\hline \multirow{2}{*}{ exon II } & 5'CGGGTCTGTTCCAGCTTGTAC 3' & 60 & \multirow{2}{*}{345} \\
\hline & 5'CACTGCACAGGCTTTAGGGAC 3' & 60 & \\
\hline \multirow{2}{*}{ exon III } & 5' TGGGCATCCCCTGGAGTATAG 3' & 60 & \multirow{2}{*}{534} \\
\hline & 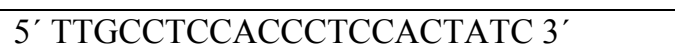 & 60 & \\
\hline \multirow{2}{*}{ exon IV } & 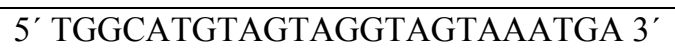 & 58 & \multirow{2}{*}{345} \\
\hline & 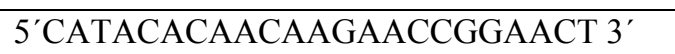 & 58 & \\
\hline
\end{tabular}

* anneling temperature

DNA samples were sequenced using an $\mathrm{ABI}$ Prism 310 automatic sequencer. For sequencing and SNP (single nucleotide polymorphism) identification, the $H F A B P$ amplified fragment was sequenced using the amplicons from the parental females, which were pooled in three DNA mixes, each one containing amplified DNA from four different females. DNA from both sires was individually sequenced. For sequencing, the amplicons were treated with the 
GFX purification kit (GE corporation), according to the instruction manual, and the reactions were carried out according to standard procedures using the ABI PRISM BigDye Terminator Cycle Sequence Ready Reaction Kit1. The program CLUSTALX (Clustalx, 2005) was used for the alignment among the generated sequences and the reference sequences, as well as for the detection of SNPs in the parental animals sequences. The program Webcutter 2.0 (Webcutter, 2005) was used for the construction of the restriction map.

After detection of the HFABP gene polymorphisms and construction of the restriction map (Table 2), 246 F2 animals were genotyped. The SNP chosen for the present study was found in fragment I in the promoter region, 314 nucleotides forward from the start codon and it was caused by the deletion of a thymine (T) (Table 3). Restriction was carried out in a reaction mixture containing $3.85 \mu 1$ water, $0.5 \mu 1$ Hinf I (equivalent to 5 units), $0.15 \mu \mathrm{l} \mathrm{BSA,} 1.5 \mu 1$ $10 \mathrm{X}$ restriction buffer, and $9 \mu \mathrm{l}$ amplified DNA in final volume of $15.0 \mu \mathrm{l}$. This mixture was incubated in a water bath at $37^{\circ} \mathrm{C}$ for $2 \mathrm{~h}$. After restriction, the samples were applied to an $8 \%$ polyacrylamide gel and were stained with $0.2 \%$ silver nitrate. The DNA fragments used for genotyping of the animals were identified.

Table 2. Detected SNPs and the restriction enzymes used for their identification in the sequences of parental sires and dams in the promoter region and in the exons of the HFABP gene

\begin{tabular}{|c|c|c|c|c|}
\hline Fragment & Position & $\begin{array}{l}\text { Nucleotide } \\
\text { change }\end{array}$ & Animal $^{\#}$ & Restriction enzyme \\
\hline \multirow{6}{*}{ I } & 90 & $\mathrm{G} \rightarrow \mathrm{A}$ & $\mathrm{J}$ & Fnu DII and Nsp BII \\
\hline & 108 & $\mathrm{~T} \rightarrow-$ & $\mathrm{J}$ & Dpn I, Hinf I, Mbo I, Tfi I, and Xho II \\
\hline & \multirow{2}{*}{264} & $\mathrm{~T} \rightarrow \mathrm{G}$ & $\mathrm{C}$ & \multirow{2}{*}{ Alw NI, Cfr 10I, Cvi RI, Msp I, and Nae I } \\
\hline & & $\mathrm{K}$ & Mix 1 & \\
\hline & \multirow{2}{*}{308} & $\mathrm{~T} \rightarrow \mathrm{C}$ & $\mathrm{C}$ & \multirow{2}{*}{$*$} \\
\hline & & $\mathrm{Y}$ & $\mathrm{J}$ and Mix 1 & \\
\hline \multirow{4}{*}{ II } & 46 & $\mathrm{C} \rightarrow-$ & $\mathrm{J}$ & * \\
\hline & 136 & $\mathrm{Y}$ & Mix 1 and Mix 3 & $*$ \\
\hline & \multirow{2}{*}{260} & $\mathrm{~A} / \mathrm{G}$ & $\mathrm{J}$ and Mix 1 & \multirow{2}{*}{$*$} \\
\hline & & $\mathrm{R}$ & Mix 3 & \\
\hline \multirow{2}{*}{ III } & \multirow{2}{*}{168} & $\mathrm{~T} \rightarrow \mathrm{C}$ & C and Mix 3 & \multirow{2}{*}{ Cac 8I, Cvi JI, Mae I, and Nhe I } \\
\hline & & $\mathrm{Y}$ & $\mathrm{J}$ & \\
\hline \multirow{5}{*}{ IV } & \multirow{2}{*}{100} & $\mathrm{C} \rightarrow \mathrm{T}$ & $\mathrm{C}$ & \multirow{2}{*}{ Sdu I } \\
\hline & & $\mathrm{Y}$ & Mix 1 and Mix 3 & \\
\hline & 304 & $\mathrm{~S}$ & Mix 3 & Eco RII, Scr FI, and Sec I \\
\hline & 316 & $\mathrm{~T} \rightarrow-$ & Mix 3 & Apa LI, Bsi HKAI, and Sdu I \\
\hline & 325 & $\mathrm{C} \rightarrow \mathrm{G}$ & $\mathrm{J}$ & Cvi JI and Msl I \\
\hline
\end{tabular}

\# $-\mathrm{C}$ and $\mathrm{J}$ are both parental sires, and mix 1, mix 2, and mix 3 are mixed amplicons from the parental dams.

*- the nucleotide change is not recognized by restriction enzymes.

$\mathrm{A}=$ adenine, $\mathrm{T}=$ thymine, $\mathrm{C}=$ cytosine, $\mathrm{G}=$ guanine, $\mathrm{Y}=\mathrm{C}$ or $\mathrm{T}, \mathrm{K}=\mathrm{T}$ or $\mathrm{G}, \mathrm{R}=\mathrm{A}$ or $\mathrm{T}, \mathrm{S}=\mathrm{C}$ or $\mathrm{G}$.

Arrows indicate the nucleotide change and dashes indicate deletion.

Table 3. Change at the Hinf I restriction site (GANTC) due to the deletion of a thymine in fragment I (promoter region)

\begin{tabular}{lll}
\hline Sequence & Mutation & Restriction fragments (bp) \\
\hline TCAGATTCCGAA* & - & 314,105, and 59 \\
TCAGAT-CCGAA & Deletion of a thymine & 314,164 \\
\hline
\end{tabular}

* the Hinf I restriction site is italicized, and the deleted nucleotide is bolded.

${ }^{1}$ Applied Biosystems - Foster City, CA - USA 
The homozygote animals for the wild allele presented three distinct bands of 314, 105, and $59 \mathrm{bp}$, and were called $\mathrm{HH}$ genotype. Heterozygote animals presenting one deleted allele, which led to the lack of recognition by the restriction enzyme, were called $\mathrm{Hh}$, being their eletrophoretic pattern characterized by fragments of $314,164,105$, and $59 \mathrm{bp}$. No homozygous animals for the deletion were observed; anyway, the eletrophoretic pattern for them should be fragments of 314 and $164 \mathrm{pb}$.

The carcass cuts and meat quality traits evaluated in the F2 generation are described in Tables 4 and 5 . Statistical analysis of the association between genotypes and the evaluated traits were performed using the following model:

$\mathrm{y}_{\mathrm{ijk} k m}=\alpha+\mathrm{G}_{\mathrm{i}}+\mathrm{S}_{\mathrm{j}}+\mathrm{B}_{\mathrm{k}}+\mathrm{S}_{1}+\left(C_{i j k l m}-\bar{C}\right) b+\mathrm{e}_{\mathrm{ijklm}}$, in which:

yijklm = trait observed in animal $\mathrm{m}$ of genotype $\mathrm{i}$, sex $\mathrm{j}$, batch $\mathrm{k}$, and sire $1 ; \alpha=$ general mean; $\mathrm{Gi}=$ fixed effect of genotype $\mathrm{i}(\mathrm{i}=1,2) ; \mathrm{Sj}=$ fixed effect of $\operatorname{sex} \mathrm{j}(\mathrm{j}=1,2$ with $1=$ castrated males, and $2=$ females); $\mathrm{Bk}=$ fixed effect of batch $\mathrm{k}(\mathrm{k}=1,2,3$, 4 , and 5); $S_{1}=$ random effect of sire $1 ; b=$ linear regression coefficient of the trait on the covariate; Cijklm= observed covariate value; and eijklm = random error.

The used covariates were: weight of the cooled right half carcass for the analysis of carcass cuts and slaughter age for the analysis of meat quality traits.

\section{RESULTS AND DISCUSSION}

Amplification under the PCR conditions of the present study showed good specificity and performance for all fragments of the $H F A B P$ gene. The size of the amplified fragments corresponded to the expected, when the molecular weight of the bands was compared on an $8 \%$ polyacrylamide gel.

The frequencies of the $\mathrm{HH}$ and $\mathrm{Hh}$ genotypes were 0.81 and 0.19 , respectively. Considering that no hh animals have been identified, the dominance and additive effects could not be estimated. The results reported by Lin et al. (2002) in a study with 561 Duroc, Landrace, Yorkshire, Nanchang White, Erhualian, Meishan, Yushan Black, Leping Spotted, Jinhua Black Head-Hind, and Shanggao Black Head-Hind pig breeds showed variations in the Hinf I-RFLP, Hae III-RFLP, and Msp I-RFLP restriction sites of the same gene; although the authors did not specify the position of the mutations.
Table 4 shows the number of observations, genotypic means, and $\mathrm{F}$ test values obtained for the analyzed carcass cuts. Significant effects were observed for kidneys weight $(\mathrm{P}<0.01)$, total loin weight $(\mathrm{P}<0.05)$, sir loin weight $(\mathrm{P}<0.10)$, and jowl weight $(\mathrm{P}<0.05)$. It is worth of mention that for the most important economic cuts, i.e. total loin and sirloin, the genotype $\mathrm{HH}$ showed the highest weights; while for the less important ones (kidneys and jowl), the genotype $\mathrm{HH}$ presented the lowest mean weights (Table 4). Urban et al. (2002) studied Large White and Landrace pigs and reported no significant effects of $H F A B P$ genotypes on the weights and percentages of carcass cuts.

In respect to the meat quality traits, Table 5 shows the number of observations, genotypic means and, the $F$ test values. No significant effects of the genotypes on meat quality traits was observed. Also, Urban et al. (2002) and Nechtelberger et al. (2001) worked with Pietrain, Large White, and Landrace pigs and found no genotype effects on those traits. On the other hand, Gerbens et al. (1999; 2000) reported significant genotype effects on intramuscular fat in two Duroc populations and in Meishan and Western pigs. In the latter study, the authors suggested that the $H F A B P$ gene might be applied to selection programs in order to increase the intramuscular fat content without a concomitant increase in backfat thickness based on the finding of significant effects of the gene on intramuscular fat but not on backfat thickness. In the present study, no genotype effect was found on fat traits, but on muscle deposition traits instead; like loin and sirloin weights. So far, this is also the first report on the effect of HFABP genotypes on weights of internal organs, specifically kidneys weight.

The Brazilian native pig Piau is originated from breeds introduced by the Portuguese settlers in the century XVI and received some influence of Dutch and African breeds (Vianna, 1985). These animals were used for breeding in small farms, having as main characteristics: rusticity, adaptability to poor conditions of management and feeding; and a great resistance to diseases. All of these old breeds are considered to be of the fat type. They supply the farmers with meat, but with a large amount of fat. However, in the last decades, due to this great amount of fat, associated to the changes in the consumer habit and the low production efficiency, these naturalized pigs are on their way to extinction (Lopes et al., 2002). 
Figueiredo et al.

Table 4. Number of observations (N) and means of carcass cuts for genotypes $\mathrm{HH}$ and $\mathrm{Hh}$ of the $H F A B P$ gene

\begin{tabular}{|c|c|c|c|c|c|}
\hline \multirow{3}{*}{ Trait } & \multicolumn{4}{|c|}{ Genotype } & \multirow{3}{*}{ SIG } \\
\hline & \multicolumn{2}{|l|}{$\mathrm{HH}$} & \multicolumn{2}{|l|}{$\mathrm{Hh}$} & \\
\hline & $\mathrm{N}$ & Mean \pm SD & $\mathrm{N}$ & Mean \pm SD & \\
\hline RHCW (kg) & 161 & $26.46 \pm 3.11$ & 39 & $26.36 \pm 2.93$ & 0.91 \\
\hline HW (kg) & 159 & $7.22 \pm 0.90$ & 39 & $7.24 \pm 0.83$ & 0.66 \\
\hline THW (kg) & 156 & $5.06 \pm 0.64$ & 39 & $5.08 \pm 0.52$ & 0.85 \\
\hline BSW (kg) & 161 & $2.34 \pm 0.36$ & 39 & $2.38 \pm 0.40$ & 0.16 \\
\hline TBSW (kg) & 161 & $1.70 \pm 0.28$ & 39 & $1.74 \pm 0.28$ & 0.12 \\
\hline PSW (kg) & 160 & $4.81 \pm 0.68$ & 37 & $4.78 \pm 0.65$ & 0.46 \\
\hline TPSW (kg) & 160 & $2.73 \pm 0.44$ & 39 & $2.78 \pm 0.42$ & 0.57 \\
\hline TLW (kg) & 157 & $3.50 \pm 0.50$ & 39 & $3.40 \pm 0.49$ & 0.05 \\
\hline LW (kg) & 160 & $1.08 \pm 0.18$ & 39 & $1.08 \pm 0.17$ & 0.96 \\
\hline BCW (kg) & 158 & $2.71 \pm 0.48$ & 39 & $2.66 \pm 0.47$ & 0.73 \\
\hline $\mathrm{BCD}(\mathrm{cm})$ & 158 & $25.72 \pm 6.12$ & 38 & $25.76 \pm 7.82$ & 0.95 \\
\hline RW (kg) & 161 & $1.56 \pm 0.25$ & 38 & $1.59 \pm 0.26$ & 0.79 \\
\hline JW (kg) & 160 & $0.72 \pm 0.20$ & 38 & $0.82 \pm 0.25$ & 0.01 \\
\hline HW (kg) & 160 & $1.52 \pm 0.22$ & 39 & $1.52 \pm 0.24$ & 0.76 \\
\hline SLW (kg) & 160 & $0.24 \pm 0.04$ & 38 & $0.23 \pm 0.04$ & 0.10 \\
\hline FW (kg) & 160 & $0.49 \pm 0.15$ & 38 & $0.46 \pm 0.14$ & 0.38 \\
\hline KW (kg) & 160 & $0.12 \pm 0.02$ & 39 & $0.13 \pm 0.02$ & 0.01 \\
\hline
\end{tabular}

$\mathrm{SD}=$ standard deviation; $\mathrm{SIG}=$ limit of significance for the $\mathrm{F}$ test.

$\mathrm{RHCW}+$ right half carcass weight, HW = skinless and fatless ham weight, THW = total ham weight, $\mathrm{BSW}=$ skinless and fatless Boston shoulder weight, TBSW = total Boston shoulder weight, PSW = skinless and fatless picnic shoulder weight, TPSW $=$ total picnic shoulder weight, TLW $=$ total (bone-in) loin weight, LW $=$ boneless loin weight, $\mathrm{BCW}=$ bacon weight, $\mathrm{BCD}=$ bacon depth, $\mathrm{RW}=$ rib weight, $\mathrm{JW}=$ jowl weight, $\mathrm{HW}=$ head weight, $\mathrm{SLW}=$ sirloin weight, $\mathrm{KW}=$ kidney weight, and $\mathrm{FW}=$ fat weight.

Table 5. Number of observations (N) and means of meat quality traits obtained for genotypes HH and Hh of the HFABP gene

\begin{tabular}{|c|c|c|c|c|c|}
\hline \multirow{3}{*}{ Trait } & \multicolumn{4}{|c|}{ Genotype } & \multirow{3}{*}{ SIG } \\
\hline & \multicolumn{2}{|r|}{$\mathrm{HH}$} & \multicolumn{2}{|r|}{$\mathrm{Hh}$} & \\
\hline & $\mathrm{N}$ & Mean \pm SD & $\mathrm{N}$ & Mean \pm SD & \\
\hline pH45 & 163 & $6.60 \pm 0.28$ & 38 & $6.62 \pm 0.31$ & 0.12 \\
\hline $\mathrm{pH} 24$ & 163 & $5.74 \pm 0.19$ & 40 & $5.75 \pm 0.16$ & 0.42 \\
\hline Luminosity & 164 & $45.11 \pm 1.95$ & 40 & $45.44 \pm 1.90$ & 0.27 \\
\hline A & 162 & $0.79 \pm 0.58$ & 40 & $0.68 \pm 0.49$ & 0.51 \\
\hline B & 165 & $6.70 \pm 0.58$ & 40 & $6.75 \pm 0.50$ & 0.40 \\
\hline IMF (\%) & 152 & $1.65 \pm 0.56$ & 37 & $1.58 \pm 0.51$ & 0.54 \\
\hline DL $(\%)$ & 164 & $3.04 \pm 1.74$ & 40 & $3.20 \pm 1.54$ & 0.98 \\
\hline $\mathrm{CL}(\%)$ & 165 & $32.48 \pm 2.39$ & 40 & $32.58 \pm 2.54$ & 0.55 \\
\hline $\mathrm{SF}(\mathrm{g} / 1.2 \mathrm{~cm})$ & 162 & $5,638.26 \pm 803.97$ & 38 & $5,635.16 \pm 959.92$ & 0.84 \\
\hline TWL (\%) & 165 & $34.39 \pm 2.65$ & 38 & $34.18 \pm 2.60$ & 0.31 \\
\hline $\mathrm{H}$ & 155 & $83.05 \pm 5.06$ & 39 & $84.27 \pm 4.20$ & 0.57 \\
\hline $\mathrm{C}$ & 159 & $6.74 \pm 0.57$ & 39 & $6.80 \pm 0.50$ & 0.33 \\
\hline
\end{tabular}

pH45 and $\mathrm{pH} 24=\mathrm{pH}$ measured 45 minutes and 24 hours post-mortem, respectively; $\mathrm{A}=$ redness; $\mathrm{B}=$ yellowness; $\mathrm{IMF}=$ intramuscular fat; $\mathrm{DL}=$ drip loss; $\mathrm{CL}=$ cooking loss; $\mathrm{OT}=$ objective tenderness (shearing force); $\mathrm{TL}=$ total loss; $\mathrm{H}=$ hue angle; $\mathrm{C}=$ chroma index.

In the present study, the lack of significant effects of the genotypes on most traits might be explained by the absence of the third genotype (hh). Another factor that might contribute to the detection of significant effects on other traits is to genotype a larger number of animals. The SNPs detected at the $H F A B P$ gene sequence allowed the construction of a restriction map in which specific enzymes recognize different allelic variants of the gene. Regardless the previously described genotype effects, no effects on fat traits were observed. In this way, it has to be considered more animals from different genetic compositions to be genotyped for the SNP here described in order to access their actual value for the marker-assisted selection. 


\section{ACKNOWLEDGMENTS}

This work was supported by Fapemig, Capes, and $\mathrm{CNPq}$.

\section{REFERENCES}

CLUSTALX, EBI tools 2005. Disponível em $<$ http://www.ebi.ac.uk/clustalw/>. Acessado em: 27 set. 2005.

DEKKERS, J. C. M. Commercial application of marker- and gene-assisted selection in livestock: Strategies and lessons. J. Anim. Sci. v.82, suppl., p.E313-E328, 2004

GERBENS, F.; VAN ERP, A.J.; HARDERS, F.L. et al. Effect of genetic variants of the heart fatty acid-binding protein gene on intramuscular fat and performance traits in pigs. J. Anim. Sci., v.77, p.846-852, 1999.

GERBENS, F.; DE KONING, D.J.; HARDERS, F.L. et al. The effect of adipocyte and heart fatty acid-binding protein genes on intramuscular fat and backfat content in Meishan crossbred pigs. $J$. Anim. Sci., v.78, p.552-559, 2000.

LIN, W.H.; HUANG, L.S.; REN, J. et al. Research on genetic variation of heart fatty acidbinding protein gene in ten pig breeds. Yi Chuan Xue Bao, PubMed- MEDLINE, v.29, p.12-15, 2002. (Abstr.)

LOPES, P.S.; GUIMARÃES, S.E.F.; PIRES, A.V. et al. Results of performance, carcass yield and meat quality traits of F2 crosses between Brazilian native and commercial pigs for QTL mapping. In: WORLD CONGRESS IN GENETICS AND ANIMAL LIVESTOCK PRODUCTION, 7. 2002, Montpellier, France. Proceedings...Montpellier, 2002. p.155
MERKS, J.W.M. One century of genetic changes in pigs and the future needs. In: HILL, W.G.; BISHOP, S.C.; MCGUIRK, B. et al. (Eds). The challenge of genetic change in animal production. Scotland: British Society of Animal Science, 2000. p.8-19.

NECHTELBERGER, D.; PIRES, V.; SOOLKNET, J. et al. Intramuscular fat content and genetic variants at fatty acid-binding protein loci in Austrian pigs. J. Anim. Sci., v.79, p.27982804, 2001.

QIAN, Q.; KUO, L.; YU, Y.T.; et al. A concise promoter region of the heart fatty acid-binding protein gene dictates tissue-appropriate expression. Circ. Res., v.8, p.4276-289, 1999

SAMBROOK, J.; FRITSH, E.F.; MANIATS, T. Molecular cloning: a laboratory manual. 2.ed. New York: Cold Spring Harbor Laboratory, 1989. 564p.

SOARES, M.A.M.; GUIMARÃES, S.E.F.; EUCLYDES, R.F., et al. Novos polimorfismos no gene da obesidade em raças divergentes de suínos. Arq. Bras. Med. Vet. Zootec., v.58, p.401-407, 2006

URBAN, T.; MIKOLASOVA, R.; KUCIEL, J. et al. A study of associations of the $H F A B P$ genotypes with fat and meat production of pigs. J. Appl. Genet., v.43, p.505-509, 2002.

VIANNA, A.T. (Ed). Os suínos. 14.ed. São Paulo: Nobel, 1985.134p.

WEBCUTTER. 2005 Disponível em: $<$ http://www.ccsi.com/firstmarket/firstmarket/cut ter/cut2.html>. Acessado em: 27 nov. 2005. 